\title{
Synthesis of $o$-brominated diaryl ethers using symmetrical iodonium salts: application to the synthesis of Bastadin precursors
}

\author{
Elias A. Couladouros*, Vassilios I. Moutsos, and Emmannuel N. Pitsinos \\ Department of Chemistry, Agricultural University of Athens, \\ Iera Odos 75, 11855 Athens, Greece \\ Organic and Bioorganic Chemistry Laboratory, NCSR Demokritos, \\ 15310 Ag. Paraskevi Attikis, PO Box 60228, Athens, Greece \\ E-mail:ecoula@chem.demokritos.gr
}

\begin{abstract}
Dedicated to Professor Anastasios Varvoglis on the occasion of his $65^{\text {th }}$ birthday
(received 10 Sep 03; accepted 18 Nov 03; published on the web 06 Jan 04)
\end{abstract}

\begin{abstract}
The coupling of $o$-brominated phenols with symmetrical iodonium salts for the construction of the corresponding diaryl ethers was studied. Bis-(2-benzyloxy-5-formyl-phenyl)-iodonium bromide $\mathbf{6 b}$, only once mentioned in the literature, was fully characterized and tested for the synthesis of Bastadin related diaryl ethers.
\end{abstract}

Keywords: Bastadins, iodonium salt, synthesis, natural products

\section{Introduction}

Diaryl ether is the common structural feature of many natural products with significant biological activity. Vancomycin is the most prominent example, since it is a very potent antibiotic and constitutes the last defense of science against the penicillin resistant Staphylococcus aureus. ${ }^{1}$ Bastadins, a family of linear or macrocyclic bis-diaryl ether tetrapeptides possessing brominated aryl units and unique $\alpha$-oximinino amide bonds, are yet another example. $^{2}$

Despite recent advances in the synthesis of diaryl ethers, ${ }^{3}$ the efficient preparation of $o$ halogenated derivatives continues to constitute a synthetic challenge with which we were faced in the course of ongoing research towards the synthesis of Bastadins. We would like to report herein results related to our studies on the construction of the o-brominated diaryl ether moiety of these natural products, based on the coupling of phenols with triazenes or iodonium salts. 


\begin{tabular}{lllll} 
& $\mathrm{Y}^{1}$ & $\mathrm{Y}^{2}$ & $\mathrm{Y}^{3}$ \\
\hline Bastadin-4 & $\mathrm{H}$ & $\mathrm{Br}$ & $\mathrm{Br}$ \\
Bastadin-7 & $\mathrm{H}$ & $\mathrm{Br}$ & $\mathrm{H}$ \\
Bastadin-11 & $\mathrm{H}$ & $\mathrm{H}$ & $\mathrm{Br}$ \\
Bastadin-14 & $\mathrm{Br}$ & $\mathrm{Br}$ & $\mathrm{H}$ \\
\hline Bastadin-8 & $\mathrm{H}$ & $\mathrm{Br}$ & $\mathrm{Br}$ \\
Bastadin-10 & $\mathrm{H}$ & $\mathrm{Br}$ & $\mathrm{H}$ \\
Bastadin-12 & $\mathrm{Br}$ & $\mathrm{Br}$ & $\mathrm{H}$ \\
Bastadin-17 & $\mathrm{H}$ & $\mathrm{H}$ & $\mathrm{Br}$ \\
Bastadin-5 & $\mathrm{H}$ & $\mathrm{Br}$ & $\mathrm{Br}$ \\
Bastadin-6 & $\mathrm{Br}$ & $\mathrm{Br}$ & $\mathrm{Br}$ \\
Bastadin-9 & $\mathrm{H}$ & $\mathrm{H}$ & $\mathrm{Br}$ \\
Bastadin-15 & $\mathrm{Br}$ & $\mathrm{Br}$ & $\mathrm{H}$ \\
Bastadin-16 & $\mathrm{Br}$ & $\mathrm{H}$ & $\mathrm{Br}$
\end{tabular}

Figure 1. Bastadins isolated from the marine sponge Ianthella basta.

\section{Results and Discussion}

According to the first method, the triazene functionality of an appropriately substituted aryl can be used to facilitate its coupling to phenols. ${ }^{4}$ Subsequent to diaryl ether formation, this directing group could be reductively or hydrolytically removed.

In order to investigate the utility of this method for the construction of diaryl ethers related to Bastadins, we opted to use as models triazenes of aniline, p-toluidine and its $o$-brominated analogs. These substrates were conveniently obtained from the corresponding diazonium salts by treatment with pyrrolidine (Scheme 1).

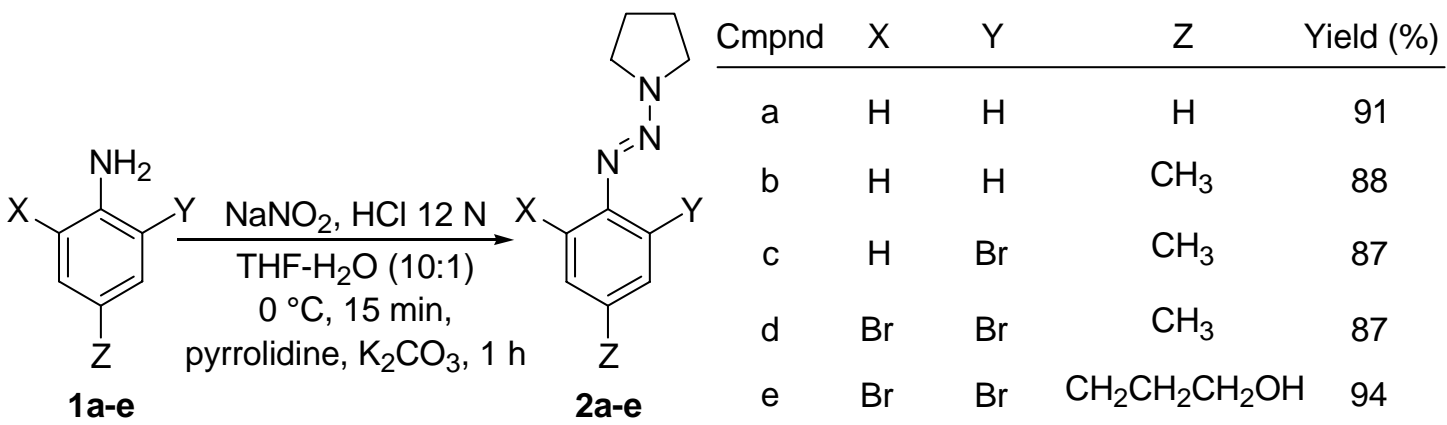

Scheme 1. Synthesis of triazenes. 
Although their coupling with simple phenols proceeded in good yields (Scheme 2) subsequent hydrolysis of the triazene group proved to be problematic (Scheme 3).

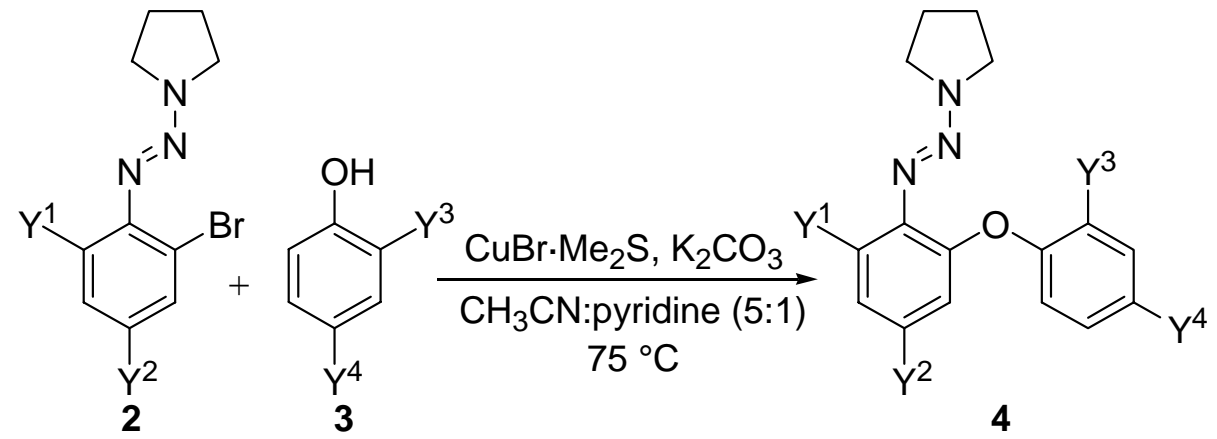

\begin{tabular}{|c|c|c|c|c|c|c|}
\hline Entry & $\mathrm{Y}^{1}$ & $Y^{2}$ & $Y^{3}$ & $Y^{4}$ & Time (h) & Product (Yield, \%) \\
\hline 1 & $\mathrm{H}$ & $\mathrm{CH}_{3}$ & $\mathrm{H}$ & $\mathrm{CH}_{3}$ & 5 & $4 a(52)$ \\
\hline 2 & $\mathrm{H}$ & $\mathrm{CH}_{3}$ & $\mathrm{H}$ & $\mathrm{CH}_{2} \mathrm{CH}_{2} \mathrm{COOEt}$ & 16 & 4b (56) \\
\hline 3 & $\mathrm{Br}$ & $\mathrm{CH}_{2} \mathrm{CH}_{2} \mathrm{CH}_{2} \mathrm{OH}$ & $\mathrm{Br}$ & $\mathrm{CH}_{2} \mathrm{CH}_{2} \mathrm{COOEt}$ & 15 & 4c (59) \\
\hline
\end{tabular}

Scheme 2. Synthesis of diaryl ethers utilizing the triazene method.

\begin{tabular}{cccccccc}
\hline Entry & Triazene & $\mathrm{X}$ & $\mathrm{Y}$ & $\mathrm{Z}$ & $\mathrm{R}$ & Conditions $^{\mathrm{a}}$ & $\begin{array}{c}\text { Yield }^{(\%)} \\
(\%)\end{array}$ \\
\hline 1 & $\mathbf{2 a}$ & $\mathrm{H}$ & $\mathrm{H}$ & $\mathrm{H}$ & $\mathrm{OH}$ & $1-4$ & $80-87$ \\
2 & $\mathbf{2 b}$ & $\mathrm{H}$ & $\mathrm{H}$ & $\mathrm{CH}_{3}$ & $\mathrm{OH}$ & 1,2 & 87 \\
3 & $\mathbf{2 c}$ & $\mathrm{H}$ & $\mathrm{Br}$ & $\mathrm{CH}_{3}$ & $\mathrm{OH}$ & 5 & 60 \\
4 & $\mathbf{2 d}$ & $\mathrm{Br}$ & $\mathrm{Br}$ & $\mathrm{CH}_{3}$ & $\mathrm{OH}$ & $1-4,6$ & - \\
5 & $\mathbf{4 b}$ & $\mathrm{H}$ & $\mathrm{OC}_{6} \mathrm{H}_{4}-p-$ & $\mathrm{CH}_{3}$ & $\mathrm{OH}$ & $1-4$ & - \\
& & & $\mathrm{CH}_{2} \mathrm{CH}_{2} \mathrm{COOEt}$ & & & & - \\
6 & $\mathbf{4 a}$ & $\mathrm{H}$ & $\mathrm{OC}_{6} \mathrm{H}_{4}-p-\mathrm{CH}_{3}$ & $\mathrm{CH}_{3}$ & $\mathrm{OH}$ & $1-4,7$ & - \\
\hline 7 & $\mathbf{2 c}$ & $\mathrm{H}$ & $\mathrm{Br}$ & $\mathrm{CH}_{3}$ & $\mathrm{H}$ & 8 & 56 \\
8 & $\mathbf{4 a}$ & $\mathrm{H}$ & $\mathrm{OC}_{6} \mathrm{H}_{4}-p-\mathrm{CH}_{3}$ & $\mathrm{CH}_{3}$ & $\mathrm{H}$ & 8 & 44 \\
9 & $\mathbf{4 a}$ & $\mathrm{H}$ & $\mathrm{OC}_{6} \mathrm{H}_{4}-p-\mathrm{CH}_{3}$ & $\mathrm{CH}_{3}$ & $\mathrm{H}$ & 9 & 37 \\
\hline 10 & $\mathbf{2 c}$ & $\mathrm{H}$ & $\mathrm{Br}$ & $\mathrm{CH}_{3}$ & $\mathrm{OCH}_{3}$ & 10 & - \\
11 & $\mathbf{2 b}$ & $\mathrm{H}$ & $\mathrm{H}$ & $\mathrm{CH}_{3}$ & $\mathrm{OCOCH}_{3}$ & 11 & 56 \\
12 & $\mathbf{2 c}$ & $\mathrm{H}$ & $\mathrm{Br}$ & $\mathrm{CH}_{3}$ & $\mathrm{OCOCH}_{3}$ & 11,12 & $\sim 5$ \\
\hline
\end{tabular}

Scheme 3. Hydrolysis of triazenes. ${ }^{\mathrm{a}}$ Reagents and conditions: $1.10 \% \mathrm{HCl}$, THF, sat.aq. $\mathrm{CuSO}_{4}$, r.t., 1 h; 2. $\mathrm{HCOOH}: \mathrm{CuSO}_{4}$ 1:10(v/v), r.t., 12 h; $3.10 \% \mathrm{HCl}$, THF, $\mathrm{Cu}\left(\mathrm{NO}_{3}\right)_{2}, \mathrm{Cu}_{2} \mathrm{O}, 0{ }^{\circ} \mathrm{C} ; 4$. $\mathrm{H}^{+}$-resin, THF, $75{ }^{\circ} \mathrm{C}, 1 \mathrm{~h} ; 5.12 \mathrm{~N} \mathrm{HCl}, \mathrm{Cu}\left(\mathrm{NO}_{3}\right)_{2}, \mathrm{Cu}_{2} \mathrm{O}, 0{ }^{\circ} \mathrm{C} \rightarrow$ r.t.; 6. TMS-Cl, $\mathrm{Cu}(\mathrm{OH})_{2}$, $\mathrm{CH}_{3} \mathrm{CN}, 60{ }^{\circ} \mathrm{C}$; 7. EtOH $95 \%$, TFA, $0{ }^{\circ} \mathrm{C} \rightarrow$ reflux; 8. TMS-Cl, NaI, $\mathrm{CH}_{3} \mathrm{CN}, 60{ }^{\circ} \mathrm{C}$; $\mathrm{MeMgBr}$, iPrMgBr, $\mathrm{B}(\mathrm{OMe})_{3} ; \mathrm{H}_{2} \mathrm{O}_{2} ; 9$. TMS-Cl, $\mathrm{NaBr}, \mathrm{CH}_{3} \mathrm{CN}, 60{ }^{\circ} \mathrm{C} ; \mathrm{MeMgBr}, i \operatorname{PrMgBr}, \mathrm{B}(\mathrm{OMe})_{3}$; 
$\mathrm{H}_{2} \mathrm{O}_{2}$; 10. TMS-Cl, NaOMe, $\mathrm{CH}_{3} \mathrm{CN}, 60{ }^{\circ} \mathrm{C} ; 11 . \mathrm{AcOH}, \mathrm{Cu}(\mathrm{OAc})_{2}, 60{ }^{\circ} \mathrm{C}, 2 \mathrm{~h} ; 12$. TMS-Cl, $\mathrm{AgOAg}, \mathrm{CH}_{3} \mathrm{CN}, 60^{\circ} \mathrm{C}$.

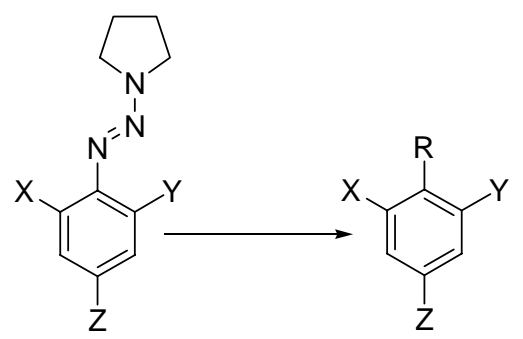

Although the non-halogenated triazenes were easily converted to the corresponding phenols under acidic conditions (Scheme 3; entries 1,2), substituted substrates required more vigorous conditions or failed all together to provide the desired products (Scheme 3; entries 3-6). Even the reported alternative indirect hydrolysis procedure, ${ }^{5}$ through the intermediacy of the corresponding aryl iodides or bromides, was unsuccessful in our hands resulting mainly to competing reduction byproducts (Scheme 3, entries 7-9). Finally, we tested the conversion of triazenes to protected phenols, which also proved to be low yielding or totally unsuccessful (Scheme 3, entries 10-12). 


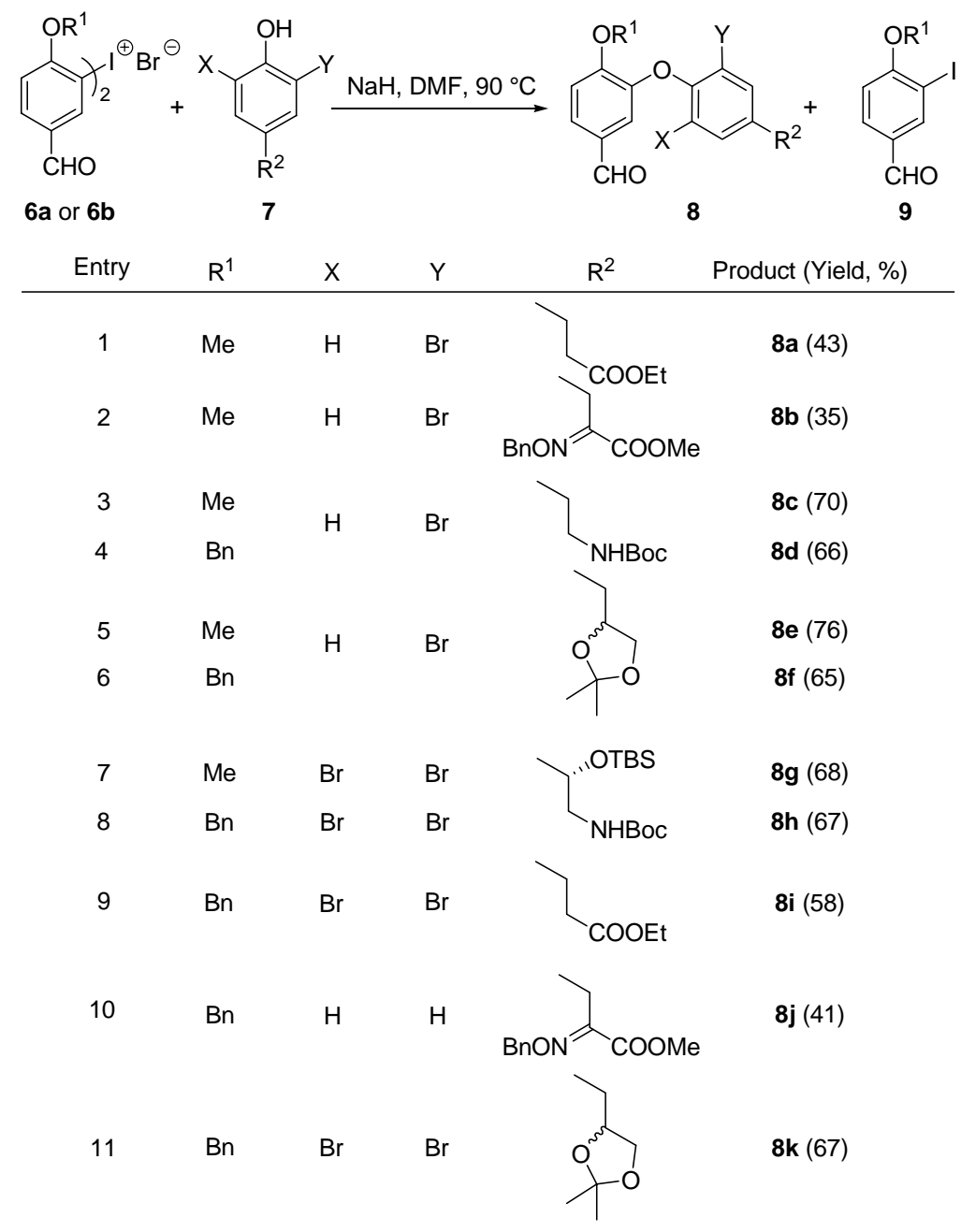

Scheme 4. Synthesis of diaryl ethers utilizing iodonium salts.

On the contrary, the iodonium salt method for the construction of diaryl ethers proved to be more fruitful. ${ }^{6}$ Coupling of the known symmetrical iodonium salt $6 \mathbf{6}\left(\mathrm{R}^{1}=\mathrm{Me}\right)$ with $o$ brominated phenols proceeds in good to fair yields (Scheme 4) and allowed us to develop an efficient and general synthetic strategy towards Bastadins.

Employing this strategy we were able to construct for the first time an unsymetrically brominated member of this class of natural products, Bastadin 12, albeit in fully protected form. Attempts to achieve its final deprotection failed, presumably due to the methyl ether protected phenol groups originating from the iodonium salt used.

Thus, we were forced to investigate alternatively protected iodonium salts. Although the most straightforward method for their construction requires cheap and either commercially available or easily prepared $p$-benzaldehyde derivatives, the conditions employed are harsh and seriously limit the repertoire of compatible protective groups for the phenol moiety. Thus, from the derivatives tested only the benzyloxy and o-nitrobenzyloxy $p$-benzaldehydes furnished the corresponding iodonium salts and only the former in synthetically useful yield (Scheme 5). 
It is noteworthy that, although the benzyl-protected iodonium salt $(\mathbf{6 b})$ has been previously utilized, no detailed experimental procedure for its preparation has been reported. ${ }^{8}$ Considerable experimentation was required to optimize the reaction conditions and yields reported herein. Gratifyingly, coupling of this iodonium salt with phenols was equally effective as its methyl protected counterpart (Scheme 4, entries 4, 6, 8 - 11).<smiles>[R]Oc1ccc(C=O)cc1</smiles>

5

TPS $=$ triphenylsilyl

$\mathrm{PMB}=p$-methoxybenzyl

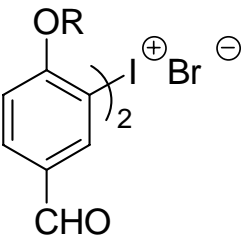

6

\begin{tabular}{ccc} 
Cmpnd & $\mathrm{R}$ & Yield (\%) \\
\hline a & $\mathrm{Me}$ & 56 \\
b & $\mathrm{Bn}$ & 42 \\
c & $\mathrm{Bn}\left(\mathrm{O}-\mathrm{NO}_{2}\right)$ & 13 \\
d & $\mathrm{H}$ & 0 \\
e & $\mathrm{TPS}$ & 0 \\
$\mathbf{f}$ & $\mathrm{PMB}$ & 0 \\
$\mathbf{g}$ & Allyl & 0
\end{tabular}

Scheme 5. Synthesis of modified iodonium salts.

\section{Conclusions}

In conclusion, the coupling of phenols with symmetrical iodonium salts provides an efficient method for the construction of densely functionalized diaryl ethers, even ortho-brominated ones. Indeed, elaboration of the diaryl ethers thus obtained to free Bastadin 12 has been successful and its total synthesis as well as that of other members of this family of natural products will be soon reported elsewhere.

\section{Experimental Section}

General Procedures. All reactions were carried out under a dry argon atmosphere with anhydrous, freshly distilled solvents under anhydrous conditions unless otherwise noted. All reactions were magnetically stirred with Teflon stir bars, and temperatures were measured externally. Reactions requiring anhydrous conditions were carried out in oven dried $\left(120{ }^{\circ} \mathrm{C}, 24\right.$ h) or flame dried (vacuum $<0.5$ Torr) glassware. Yields refer to chromatographically and spectroscopically ( ${ }^{1} \mathrm{H}$ NMR) homogeneous materials. All reagents were obtained from Aldrich Chemical Co. Inc. and used without further purification. All reactions were monitored by thin layer chromatography (TLC) carried out on $0.25-\mathrm{mm}$ E.Merck silica gel plates (60F-254). E.Merck silica gel (60, particle size 0.040-0.063 $\mathrm{mm}$ ) was used for flash column chromatography. Infrared spectra (IR) were recorded on Nicolet, Magna FT-IR 550, mass 
spectra were recorded using a VG ZAB ZSE instrument, optical rotations were recorded using a Perkin-Elmer 241 polarimeter. Samples were analysed as neat films on sodium chloride plates. Nuclear magnetic resonance (NMR) spectra were recorded on a Bruker AM-250 instrument. Chemical shifts are measured in parts per million $(\delta)$ relative to the deuterated solvent used in the experiment. Multiplicities are designated as singlet (s), doublet (d), triplet (t), or multiplet (m).

3-[3,5-Dibromo-4-(pyrrolidin-1-ylazo)-phenyl]-propan-1-ol (2e). To a solution of 3.0 g 3-(4amino-3,5-dibromo-phenyl)-propan-1-ol 1 e $(9.7 \mathrm{mmol})$ in THF $(50 \mathrm{~mL})$ at ambient temperature were added $4 \mathrm{~mL}$ of concentrated $\mathrm{HCl}$. To this stirred mixture was added dropwise at $0{ }^{\circ} \mathrm{C} \mathrm{a}$ solution of $\mathrm{NaNO}_{2}(870 \mathrm{mg}, 12.62 \mathrm{mmol})$ in $1 \mathrm{~mL}$ of water followed, after $15 \mathrm{~min}$, by pyrrolidine $(6.4 \mathrm{~mL}, 77.7 \mathrm{mmol})$. Upon completion of the reaction the mixture was partitioned between water and ethyl acetate. The organic layer was washed with brine, dried $\left(\mathrm{MgSO}_{4}\right)$, concentrated and purified by flash column chromatography (30\% ethyl acetate in hexane) to give $3.6 \mathrm{~g}(94 \%)$ of the corresponding dibromotriazene $2 \mathrm{e}$ as white amorphous solid; $v_{\max } / \mathrm{cm}^{-1} 3350$, $2935,2860,1525,1405,1310,1220,1155,1050,755,730,670 ; \delta_{\mathrm{H}}\left(250 \mathrm{MHz}, \mathrm{CDCl}_{3}\right) 7.30(\mathrm{~s}$, 2H, Ar), 4.00-3.60 (br d, 4H, $\mathrm{CH}_{2} \mathrm{NCH}_{2}$ ), 3.55 (t, $J=5.7 \mathrm{~Hz}, 2 \mathrm{H}, \mathrm{CH}_{2} \mathrm{OH}$ ), 2.60 (t, $J=7.6 \mathrm{~Hz}$, $2 \mathrm{H}, \mathrm{ArCH}$ ), 2.20-1.90 (br s, 4H, $\mathrm{CH}_{2} \mathrm{CH}_{2} \mathrm{NCH}_{2} \mathrm{CH}_{2}$ ), 1.70-1.60 (m, $2 \mathrm{H}, \mathrm{ArCH}_{2} \mathrm{CH}_{2}$ ); FAB HRMS (NBA) m/e 389.9824/392/394, $(\mathrm{M}+\mathrm{H})^{+}$for $\mathrm{C}_{13} \mathrm{H}_{17} \mathrm{Br}_{2} \mathrm{~N}_{3} \mathrm{O}$ requires $389.9817 / 392 / 394$.

\section{3-\{3-Bromo-4-[3-bromo-5-(3-hydroxy-propyl)-2-(pyrrolidin-1-ylazo)-phenoxy]-phenyl\}-}

propionic acid ethyl ester (4c). To a solution of dibromotriazene $2 \mathrm{e}(770 \mathrm{mg}, 1.97 \mathrm{mmol})$ and bromophenol 3c $(538 \mathrm{mg}, 1.97 \mathrm{mmol})$ in $3 \mathrm{~mL}$ of $\mathrm{CH}_{3} \mathrm{CN} /$ pyridine $5: 1(\mathrm{v} / \mathrm{v})$ was added $\mathrm{K}_{2} \mathrm{CO}_{3}$ $(680 \mathrm{mg}, 4.92 \mathrm{mmol})$ and $\mathrm{CuBr} \cdot \mathrm{Me}_{2} \mathrm{~S}(1.0 \mathrm{~g}, 4.92 \mathrm{mmol})$. The mixture was heated with stirring at $75{ }^{\circ} \mathrm{C}$ for $15 \mathrm{~h}$. Upon completion of the reaction the mixture was partitioned between a saturated aqueous solution of $\mathrm{CuSO}_{4}$ and ethyl acetate. The organic layer was washed with water and brine, dried $\left(\mathrm{MgSO}_{4}\right)$, concentrated and purified by flash column chromatography $(30 \%$ ethyl acetate in hexane) to give $678 \mathrm{mg}(59 \%)$ of diaryl ether $\mathbf{4 c}$ as white amorphous solid; $v_{\max } / \mathrm{cm}^{-1} 3440,3035,2975,2940,2870,1730,1600,1550,1485,1410,1340,1320,1270,1235$, 1160, 1040, 680; $\delta_{\mathrm{H}}\left(250 \mathrm{MHz}, \mathrm{CDCl}_{3}\right) 7.37(\mathrm{~d}, J=2.0 \mathrm{~Hz}, 1 \mathrm{H}, \mathrm{Ar}), 7.30+7.11(2 \mathrm{x} \mathrm{d}, J=1.8$ $\mathrm{Hz}, 1 \mathrm{H}, \mathrm{Ar}), 6.95(\mathrm{dd}, J=8.5,2.0 \mathrm{~Hz}, 1 \mathrm{H}, \mathrm{Ar}), 6.88+6.85(2 \mathrm{x} \mathrm{d}, J=1.8 \mathrm{~Hz}, 1 \mathrm{H}, \mathrm{Ar}), 6.59+$ $6.58(2 \mathrm{x} \mathrm{d}, J=8.5 \mathrm{~Hz}, 1 \mathrm{H}, \mathrm{Ar}), 4.15\left(\mathrm{q}, J=7.1 \mathrm{~Hz}, 2 \mathrm{H}, \mathrm{COOCH}_{2} \mathrm{CH}_{3}\right), 3.75-3.30$ (br d, $4 \mathrm{H}$, $\mathrm{CH}_{2} \mathrm{NCH}_{2}$ ), 3.65 (t, $\left.J=6.1 \mathrm{~Hz}, 2 \mathrm{H}, \mathrm{CH}_{2} \mathrm{OH}\right), 2.85$ (t, $\left.J=7.3 \mathrm{~Hz}, 2 \mathrm{H}, \mathrm{ArCH}_{2} \mathrm{CH}_{2} \mathrm{COOEt}\right), 2.65$ (t, $J=7.3 \mathrm{~Hz}, 2 \mathrm{H}, \mathrm{CH}_{2} \mathrm{COOEt}$ ), 2.55 (t, $J=7.6 \mathrm{~Hz}, 2 \mathrm{H}, \mathrm{ArCH}_{2} \mathrm{CH}_{2} \mathrm{CH}_{2} \mathrm{OH}$ ), 1.95-1.85 (br s, $4 \mathrm{H}$, $\mathrm{CH}_{2} \mathrm{CH}_{2} \mathrm{NCH}_{2} \mathrm{CH}_{2}$ ), 1.85 (m, $2 \mathrm{H}, \mathrm{ArCH}_{2} \mathrm{CH}_{2} \mathrm{CH}_{2} \mathrm{OH}$ ), 1.25 (t, $\mathrm{J}=7.1 \mathrm{~Hz}, 3 \mathrm{H}, \mathrm{COOCH}_{2} \mathrm{CH}_{3}$ ); FAB HRMS (NBA) m/e 582.0589/584/586, $(\mathrm{M}+\mathrm{H})^{+}$for $\mathrm{C}_{24} \mathrm{H}_{29} \mathrm{Br}_{2} \mathrm{~N}_{3} \mathrm{O}_{4}$ requires $582.0603 / 584 / 586$.

\section{3-[2-Bromo-4-(2,2-dimethyl-[1,3]dioxolan-4-ylmethyl)-phenoxy]-4-methoxy-benzaldehyde}

(8e). A stirred solution of the appropriate bromophenol $(6.0 \mathrm{~g}, 21 \mathrm{mmol})$ in $115 \mathrm{~mL}$ DMF was cooled at $0{ }^{\circ} \mathrm{C}$. Sodium hydride $(550 \mathrm{mg}, 23 \mathrm{mmol}$ ) was added in small portions followed by a catalytic amount of imidazole. The mixture was allowed to warm to ambient temperature and was stirred at this temperature for $30 \mathrm{~min}$. Subsequently iodonium salt $\mathbf{6 a}^{6 \mathrm{a}}(11.0 \mathrm{~g}, 23 \mathrm{mmol})$ was added and the mixture was heated at $90{ }^{\circ} \mathrm{C}$ for $3 \mathrm{~h}$. Upon completion of the reaction the 
mixture was partitioned between water and ethyl acetate. The organic layer was washed with water and brine, dried $\left(\mathrm{MgSO}_{4}\right)$, concentrated and purified by flash column chromatography (20\% ethyl acetate in hexane) to give $6.7 \mathrm{~g} \mathrm{(76 \% )}$ of diaryl ether 8e as white amorphous solid; $v_{\max } / \mathrm{cm}^{-1} 2994,2938,1698,1603,1513,1496,1440,1293,1242,1121,1065,1048,1022,816$; $\delta_{\mathrm{H}}\left(250 \mathrm{MHz}, \mathrm{CDCl}_{3}\right) 9.75(\mathrm{~s}, 1 \mathrm{H}, \mathrm{CHO}), 7.55(\mathrm{dd}, J=8.2,1.9 \mathrm{~Hz}, 1 \mathrm{H}, \mathrm{Ar}), 7.42(\mathrm{~d}, J=1.9 \mathrm{~Hz}$, $1 \mathrm{H}, \operatorname{Ar}), 7.22$ (d, $J=1.9 \mathrm{~Hz}, 1 \mathrm{H}, \mathrm{Ar}), 7.02$ (dd, $J=8.6,1.9 \mathrm{~Hz}, 1 \mathrm{H}, \mathrm{Ar}), 7.01$ (d, $J=8.2 \mathrm{~Hz}, 1 \mathrm{H}$, $\mathrm{Ar}), 6.72(\mathrm{~d}, J=8.6 \mathrm{~Hz}, 1 \mathrm{H}, \mathrm{Ar}), 4.25\left(\mathrm{~m}, 1 \mathrm{H}, \mathrm{ArCH}_{2} \mathrm{CHCH}_{2}\right), 3.93$ (dd, J=7.8, $6.0 \mathrm{~Hz}, 1 \mathrm{H}$, $\left.\mathrm{ArCH}_{2} \mathrm{CHCHH}\right), 3.53\left(\mathrm{dd}, J=7.8,7.1 \mathrm{~Hz}, 1 \mathrm{H}, \mathrm{ArCH}_{2} \mathrm{CHCHH}\right), 3.85$ (s, 3H, $\left.\mathrm{ArOCH}_{3}\right), 2.84$ $(\mathrm{dd}, J=13.8,6.3 \mathrm{~Hz}, 1 \mathrm{H}, \mathrm{ArCHH}), 2.67(\mathrm{dd}, J=13.8,6.3 \mathrm{~Hz}, 1 \mathrm{H}, \operatorname{ArCHH}), 1.35(\mathrm{~s}, 3 \mathrm{H}$, $\left.\mathrm{CH}_{3} \mathrm{CCH}_{3}\right), 1.25\left(\mathrm{~s}, 3 \mathrm{H}, \mathrm{CH}_{3} \mathrm{CCH}_{3}\right) ; \delta_{\mathrm{C}}\left(62.5 \mathrm{MHz}, \mathrm{CDCl}_{3}\right)$ 190.0, 155.5, 151.6, 145.9, 134.9, 134.2, 129.9, 129.4, 128.1, 119.1, 118.0, 113.8, 112.0, 109.1, 75.9, 68.6, 56.1, 38.7, 26.8, 25.5; FAB HRMS (NBA) m/e 421.0640/423, $(\mathrm{M}+\mathrm{H})^{+}$for $\mathrm{C}_{20} \mathrm{H}_{21} \mathrm{BrO}_{5}$ requires 421.0651/423.

2(S)-\{2-(tert-Butyl-dimethyl-silanyloxy)-2-[3,5-dibromo-4-(5-formyl-2-methoxy-phenoxy)phenyl]-ethyl\}-carbamic acid tert-butyl ester (8g). In analogy to the above procedure $4.3 \mathrm{~g}$ $(68 \%)$ of diaryl ether $8 \mathrm{~g}$ were obtained as white amorphous solid; $[\alpha]_{\mathrm{D}}+10.7\left(\mathrm{CH}_{2} \mathrm{Cl}_{2}, c=0.14\right)$; $v_{\max } / \mathrm{cm}^{-1} 3600$ - 3100, 2956, 2931, 2857, 1713, 1696, 1601, 1512, 1453, 1277, 1252, 1171, $1114,837,779,737 ; \delta_{\mathrm{H}}\left(250 \mathrm{MHz}, \mathrm{CDCl}_{3}\right) 9.70(\mathrm{~s}, 1 \mathrm{H}, \mathrm{CHO}), 7.50$ (br s, 2H, Ar), 7.48 (dd, J= 8.6, 1.9 Hz, 1H, Ar), 7.02 (d, $J=8.6 \mathrm{~Hz}, 1 \mathrm{H}, \mathrm{Ar}), 6.80$ (d, J=1.9 Hz, 1H, Ar), 4.80-4.60 (m, 2H, ArCHOTBS + NHBoc), $3.95\left(\mathrm{~s}, 3 \mathrm{H}, \mathrm{ArOCH}_{3}\right), 3.32(\mathrm{~m}, 1 \mathrm{H}, \mathrm{CHHNHBoc}), 3.00(\mathrm{~m}, 1 \mathrm{H}$, CHHNHBoc), 1.35 (s, 9H, $\left.{ }^{t} \mathrm{BuOCO}\right), 0.85$ (s, 9H, $\left.{ }^{t} \mathrm{BuSi}\right), 0.00$ (s, 3H, $\mathrm{CH}_{3} \mathrm{Si}$ ), -0.15 (s, 3H, $\left.\mathrm{CH}_{3} \mathrm{Si}\right) ; \delta_{\mathrm{C}}\left(62.5 \mathrm{MHz}, \mathrm{CDCl}_{3}\right)$ 190.4, 155.8, 154.2, 147.8, 146.2, 143.0, 130.7, 129.8, 127.5 , $118.1,112.9,111.9,79.6,72.3,56.5,48.9,28.4,25.8,18.2,3.3,3.1$; FAB HRMS (NBA/CsI) $m / e$ 791.9812/794, $(\mathrm{M}+\mathrm{Cs})^{+}$for $\mathrm{C}_{27} \mathrm{H}_{37} \mathrm{Br}_{2} \mathrm{NO}_{6} \mathrm{Si}$ requires 791.9791/794.

Bis-(2-benzyloxy-5-formyl-phenyl)-iodonium bromide (6b). To a $250 \mathrm{~mL}$ round bottom flask equipped with an efficient mechanical stirrer were added successively $\mathrm{KIO}_{3}(6.74 \mathrm{~g}, 31.5 \mathrm{mmol})$, $\mathrm{AcOH}(10 \mathrm{~mL})$ and $\mathrm{Ac}_{2} \mathrm{O}(15 \mathrm{~mL})$. The reaction was placed in an ice bath and concentrated $\mathrm{H}_{2} \mathrm{SO}_{4}(6.74 \mathrm{~mL})$ was added dropwise. p-Benzyloxybenzaldehyde (20 g, $\left.94.3 \mathrm{mmol}\right)$ was dissolved with gentle heating and stirring in $30 \mathrm{~mL}$ AcOH. This solution was allowed to cool to ambient temperature and added dropwise to the reaction mixture. During the addition, when the aldehyde was crystallizing out of the added solution it was redissolved with gentle heating and stirring and the solution was allowed to cool to ambient temperature before resuming its addition to the reaction mixure. The vessel containing the aldehyde was washed with AcOH $(10 \mathrm{~mL})$ and the washings were added to the reaction mixture. The reaction mixture was protected from light and stirring was continued for $2 \mathrm{~h}$ at $0{ }^{\circ} \mathrm{C}$ and then for $24 \mathrm{~h}$ at ambient temperature. During the course of the reaction the initially formed thick light orange suspension turned to a dark brown solution. This solution was poured into a vigorously stirred solution of $\mathrm{KBr}(4.6 \mathrm{~g}, 37 \mathrm{mmol})$ in $84 \mathrm{~mL}$ of water. A gummy precipitate formed. The supernatant was decanted and the precipitate was washed successively with diethyl ether $(3 \times 40 \mathrm{~mL})$, water $(3 \times 50 \mathrm{~mL})$ and acetone $(2 \times 20$ $\mathrm{mL}$ ). The final off-white amorphous solid was air-dried on a Büchner funnel and then further dried in a descicator over $\mathrm{CaCl}_{2}$ under reduced pressure for 2 days to provide $12.4 \mathrm{~g}(42 \%)$ of iodonium salt $\mathbf{6 b} ; v_{\max } / \mathrm{cm}^{-1} 1768,1695,1590,1484,1197,747,699 ; \delta_{\mathrm{H}}\left(250 \mathrm{MHz}, \mathrm{CDCl}_{3}\right) 9.76$ 
(s, 1H, CHO), 8.50 (d, $J=1.9 \mathrm{~Hz}, 1 \mathrm{H}, \mathrm{Ar}), 8.08$ (dd, $J=8.8,1.9 \mathrm{~Hz}, 1 \mathrm{H}, \mathrm{Ar}), 7.43$ (d, $J=8.8$ $\mathrm{Hz}, 1 \mathrm{H}, \mathrm{Ar}$ ), 7.40-7.28 (bant, 5H, Ar), 5.31 (s, 2H, $\left.\mathrm{CH}_{2} \mathrm{Ph}\right) ; \delta_{\mathrm{C}}\left(62.5 \mathrm{MHz}, \mathrm{DMSO}-\mathrm{d}_{6}\right)$ 189.9, $159.6,138.5,135.2,135.0,130.9,128.5,128.3,127.6,113.8,110.6,71.1$; FAB HRMS (NBA) m/e 549.0561, $\mathrm{M}^{+}$for $\mathrm{C}_{28} \mathrm{H}_{22} \mathrm{IO}_{4}$ requires 549.0557.

2(S)-\{2-[4-(2-Benzyloxy-5-formyl-phenoxy)-3,5-dibromo-phenyl]-2-(tert-butyl-dimethylsilanyloxy)-ethyl -carbamic acid tert-butyl ester (8h). A stirred solution of the appropriate phenol (1.5 g, $2.9 \mathrm{mmol})$ in $16 \mathrm{~mL}$ DMF was cooled at $0{ }^{\circ} \mathrm{C}$. Sodium hydride $(76 \mathrm{mg}, 3.2 \mathrm{mmol})$ was added in small portions followed by a catalytic amount of imidazole. The mixture was allowed to warm to ambient temperature and was stirred at this temperature for $30 \mathrm{~min}$. Subsequently iodonium salt $6 \mathbf{b}(2.0 \mathrm{~g}, 3.2 \mathrm{mmol})$ was added and the mixture was heated at $90{ }^{\circ} \mathrm{C}$ for $3.5 \mathrm{~h}$. Upon completion of the reaction the mixture was partitioned between water and ethyl acetate. The organic layer was washed with water and brine, dried $\left(\mathrm{MgSO}_{4}\right)$, concentrated and purified by flash column chromatography (20\% ethyl acetate in hexane) to give $1.4 \mathrm{~g}(67 \%)$ of diaryl ether $\mathbf{8 h}$ as white amorphous solid; $[\alpha]_{\mathrm{D}}+7.0\left(\mathrm{CH}_{2} \mathrm{Cl}_{2}, c=0.97\right) ; v_{\max } / \mathrm{cm}^{-1} 3600-3100$, $2957,2932,2857,1716,1696,1602,1510,1454,1280,1256,1169,1118,839,780,740 ; \delta_{\mathrm{H}}(250$ $\mathrm{MHz}_{\mathrm{CDCl}}$ ) 9.70 (s, 1H, CHO), 7.59 (br s, 2H, Ar), 7.47 (dd, J=8.2, $1.9 \mathrm{~Hz}, 1 \mathrm{H}, \mathrm{Ar}$ ), 7.407.25 (bant, $5 \mathrm{H}, \mathrm{Ar}$ ), 7.08 (d, $J=8.2 \mathrm{~Hz}, 1 \mathrm{H}, \mathrm{Ar}), 6.92$ (d, $J=1.9 \mathrm{~Hz}, 1 \mathrm{H}, \mathrm{Ar}), 5.32$ (s, 2H, $\left.\mathrm{CH}_{2} \mathrm{Ph}\right), 4.92-4.74(\mathrm{~m}, 2 \mathrm{H}$, ArCHOTBS + NHBoc), $3.39(\mathrm{~m}, 1 \mathrm{H}, \mathrm{CHHNHBoc}), 3.07$ (m, 1H, CHHNHBoc), 1.43 (s, 9H, $\left.{ }^{t} \mathrm{BuOCO}\right), 0.90$ (s, 9H, $\left.{ }^{t} \mathrm{BuSi}\right), 0.07$ (s, 3H, $\mathrm{CH}_{3} \mathrm{Si}$ ), -0.03 (s, 3H, $\left.\mathrm{CH}_{3} \mathrm{Si}\right) ; \delta_{\mathrm{C}}\left(62.5 \mathrm{MHz}, \mathrm{CDCl}_{3}\right)$ 190.3, 155.7, 153.0, 147.8, 146.6, 142.8, 135.9, 130.5, 129.9, 128.6, 128.1, 127.2, 127.1, 118.0, 113.9, 113.1, 79.5, 72.1, 70.9, 48.9, 28.3, 25.7, 18.1, 3.2, 3.0; FAB HRMS (NBA/NaI) m/e 756.0966/758/760, (M+Na) ${ }^{+}$for $\mathrm{C}_{33} \mathrm{H}_{41} \mathrm{Br}_{2} \mathrm{NO}_{6} \mathrm{Si}$ requires $756.0962 / 758 / 760$.

\section{4-Benzyloxy-3-[2-bromo-4-(2,2-dimethyl-[1,3]dioxolan-4-ylmethyl)-phenoxy]-benzaldehyde}

(8f). In analogy to the above procedure $7.6 \mathrm{~g} \mathrm{(65 \% )}$ of diaryl ether 8f were obtained as colorless oil; $\delta_{\mathrm{H}}\left(250 \mathrm{MHz}, \mathrm{CDCl}_{3}\right) 9.71(\mathrm{~s}, 1 \mathrm{H}, \mathrm{CHO}), 7.51(\mathrm{dd}, J=8.6,2.2 \mathrm{~Hz}, 1 \mathrm{H}, \mathrm{Ar}), 7.40(\mathrm{~d}, J=2.2$ $\mathrm{Hz}, 1 \mathrm{H}, \mathrm{Ar}), 7.32$ (d, $J=1.9 \mathrm{~Hz}, 1 \mathrm{H}, \mathrm{Ar}), 7.25-7.15$ (m, 5H, Ar), 7.02 (d, J=8.6 Hz, 1H, Ar), 6.99 (dd, $J=8.6,1.9 \mathrm{~Hz}, 1 \mathrm{H}, \mathrm{Ar}), 6.69$ (d, $J=8.6 \mathrm{~Hz}, 1 \mathrm{H}, \mathrm{Ar}), 5.13$ (s, 2H, OCH $\mathrm{OH}_{2}$ ), 4.20 (p, $J$ $\left.=6.3 \mathrm{~Hz}, 1 \mathrm{H}, \mathrm{ArCH}_{2} \mathrm{CHCH}_{2}\right), 3.90\left(\mathrm{dd}, J=8.2,6.0 \mathrm{~Hz}, 1 \mathrm{H}, \mathrm{ArCH}_{2} \mathrm{CHCHH}\right), 3.52(\mathrm{dd}, J=8.2$, $\left.7.1 \mathrm{~Hz}, 1 \mathrm{H}, \mathrm{ArCH}_{2} \mathrm{CHCHH}\right), 2.83(\mathrm{dd}, J=13.8,6.3 \mathrm{~Hz}, 1 \mathrm{H}, \mathrm{ArCHH}), 2.66(\mathrm{dd}, J=13.8,6.3 \mathrm{~Hz}$, $1 \mathrm{H}, \mathrm{ArCHH}), 1.33\left(\mathrm{~s}, 3 \mathrm{H}, \mathrm{CH}_{3} \mathrm{CCH}_{3}\right), 1.26\left(\mathrm{~s}, 3 \mathrm{H}, \mathrm{CH}_{3} \mathrm{CCH}_{3}\right) ; \delta_{\mathrm{C}}\left(62.5 \mathrm{MHz}, \mathrm{CDCl}_{3}\right) 190.2$, $154.8,152.2$, 146.3, 135.7, 134.7, 134.4, 130.4, 129.4, 128.6, 128.2, 128.1, 126.9, 119.3, 118.9, 114.1, 113.8, 109.3, 76.2, 70.8, 68.8, 38.9, 27.0, 25.7; FAB HRMS (NBA/NaI) m/e $519.0792 / 521,(\mathrm{M}+\mathrm{Na})^{+}$for $\mathrm{C}_{26} \mathrm{H}_{25} \mathrm{BrO}_{5}$ requires 519.0777/521.

\section{Acknowledgments}

We would like to thank G.S.R.T. for financial support, VIM would like to thank National Scholarship Foundation of Greece for a scholarship. 


\section{References}

1. (a) Nicolaou, K. C.; Boddy, C. N. C.; Bräse, S.; Wissinger, N. Angew. Chem. Int. Ed. 1999, 38, 2096. (b) Rao, A. V. R.; Gurjar, M. K.; Reddy, K. L.; Rao, A. S. Chem. Rev. 1995, 95, 2135.

2. (a) Kazlauskas, R.; Lidgard, R. O.; Murphy, P. T.; Wells, R. J. Tetrahedron Lett. 1980, 21, 2277. (b) Kazlauskas, R.; Lidgard, R. O.; Murphy, P. T.; Wells, R. J.; Blount, J. F. Aust. J. Chem. 1981, 34, 765. (c) Miao, S.; Andersen, R. J. J. Nat. Prod. 1990, 53, 1441. (d) Pordesimo, E. O.; Schmitz, F. J. J. Org. Chem. 1990, 55, 4704. (e) Butler, M. S.; Lim, T. K.; Capon, R. J.; Hammond, L. S. Aust. J. Chem. 1991, 44, 287. (f) Dexter, A. F.; Garson, M. J. J. Nat. Prod. 1993, 56, 782. (g) Carney, J. R.; Scheuer, P. J.; Kelly-Borges, M. J. Nat. Prod. 1993, 56, 153. (h) Gulavita, N. K.; Wright, A. E.; McCarthy, P. J.; Pomponi, S. A.; KellyBorges, M.; Chin, M.; Sills, M. A. J. Nat. Prod. 1993, 56, 1613. (i) Park, S. K.; Jurek, J.; Carney, J. R.; Scheuer, P. J. J. Nat. Prod. 1994, 57, 407.

3. Bailey, K. L.; Molinski, T. F. J. Org. Chem. 1999, 64, 2500 and references cited therein.

4. Nicolaou, K. C.; Boddy, C. N. C.; Natarajan, S.; Yue, T.-Y.; Li, H.; Bräse, S.; Ramanjulu, J. M. J. Am. Chem. Soc. 1997, 119, 3421.

5. Nicolaou, K. C.; Takayanagi, M.; Jain, N. F.; Natarajan, S.; Koumbis, A. E.; Bando, T.; Ramanjulu, J. M. Angew. Chem. Int. Ed. 1998, 37, 2717.

6. (a) Beringer, F. M.; Drexler, M.; Gindler, E. M.; Lumpkin, C. C. J. Am. Chem. Soc. 1953, 75, 2705. (b) Beringer, F. M.; Brierley, A.; Drexler, M.; Gindler, E. M.; Lumpkin, C. C. ibid. 1953, 75, 2708. (c) Beringer, F. M.; Falk, R. A.; Karniol, M.; Lillien, I.; Masullo, G.; Mausner, M.; Sommer, E. J. Am. Chem. Soc. 1959, 81, 342. (d) Dibbo, A.; Stephenson, L.; Walker, T.; Warburton, W. K. J. Chem. Soc. 1961, 2645. (e) Crowder, J. R.; Glover, E. E.; Grundon, M. F.; Kaempfen, H. X. J. Chem. Soc. 1963, 4578. (f) Hickey, D. M. B.; Leeson, P. D.; Novelli, R.; Shah, V. P.; Burpitt, B. E.; Crawford, L. P.; Davies, B. J.; Mitchell, M. B.; Pancholi, K. D.; Tuddenham, D.; Lewis, N. J.; O’Farrell, C. J. Chem. Soc., Perkin Trans. I 1988, 3103. (g) Crimmin, M. J.; Brown, A. G. Tetrahedron Lett. 1990, 31, 2017. (h) Chakraborty, T. K.; Reddy, G. V. J. Org. Chem. 1992, 57, 5462.

7. (a) Couladouros, E. A.; Moutsos, V. I. Tetrahedron Lett. 1999, 40, 7023. (b) Couladouros, E. A.; Moutsos, V. I. Tetrahedron Lett. 1999, 40, 7027.

8. Humora, M. J.; Seitz, D. E.; Quick, J. Tetrahedron Lett. 1980, 21, 3971. 